Article

\title{
Study to determine levels of heavy metals in cocoa crops applied to inland areas of Peru:"The case of the Campo Verde-Honoria Tournavista Corridor"
}

\author{
Jimmy Aurelio Rosales-Huamani $1, * \ddagger ®$, Jorge Luis Breña-Ore $1, \neq \oplus$,Svitlana Sespedes-Varkarsel \\ 1, $\ddagger$, Luis Huamanchumo de la Cuba ${ }^{1, \ddagger}$, Luis Centeno-Rojas ${ }^{1, \ddagger}$,Alonso Otiniano-Zavala ${ }^{1, \ddagger}$, Joseps \\ Andrade-Choque ${ }^{1, \ddagger} \mp$, Santiago Valverde-Espinoza ${ }^{1, \ddagger}$ and Jose Luis Castillo-Sequera ${ }^{2, \ddagger(\mathbb{C})}$ \\ 1 Multidisciplinary Sensing and Universal Accessibility Group, National University of Engineering,Lima \\ 1533,Peru; jorge.brena.o@uni.edu.pe, ssespedesv@uni.edu.pe ,lhuamanchumo@uni.edu.pe , \\ lcentenor@uni.pe, alonso.otiniano.z@uni.pe, jandradec@uni.pe, svalverde@uni.edu.pe \\ 2 Department of Computer Science, Higher Polytechnic School, University of Alcala, 28871 Alcalá de Henares, \\ Spain; jluis.castillo@uah.es \\ * Correspondence: jrosales@uni.edu.pe; Tel.: +51-1-381-5639 \\ $\ddagger$ These authors contributed equally to this work.
}

\begin{abstract}
The presence of heavy metals in cocoa crops is currently a serious problem for farmers and producers in various regions of Peru. Exports of cocoa and its derivatives to European markets are threatened by possible indications of contamination of heavy metals such as Cadmium (Cd) in cocoa beans for export, some at levels higher than those allowed by food regulations established by European Community, which are oriented to consumer protection. The possible sources of cadmium contamination in cocoa crops can be due to natural activities, such as volcanic activities, erosion processes and sedimentation in rocks that contain minerals with a high content of heavy metals (Greenockite, Burnsite, Hawleite, among others), and by anthropogenic activities such as: mining of associated deposits, agriculture (use of fertilizers), smelting of minerals and burning of fossil fuels. Currently, there is no information about contents of heavy metals in areas located in The Campo Verde-Honoria-Tournavista corridor (Ucayali Region and Huanuco Region), due to this, in this work we make a study of this region. A methodology will be used to take cocoa samples from the seed and soil in these areas, and then through chemical analysis, determine the concentrations of heavy metals, using an atomic absorption spectrophotometer. As a consequence of this study, we determined and concluded that the concentrations of cadmium obtained in soils are slightly higher than European standards allowed. Therefore, with this information we prepare a geochemical cadmium map in soils for the study area, which will help cocoa producers to identify areas that exceed the allowed cadmium values, in order to comply with standards that European Community demands in relation of concentration levels of heavy metals (Cadmium) in chocolate. In this way, we can carry out in the future a mitigation plan for areas with cadmium problems, which allows to reduce their content in order to export the product without any problem. .
\end{abstract}

Keywords: cocoa seed; cocoa beans; heavy metals; Cadmium

\section{Introduction}

In Peru, cocoa is currently an important item for exports that generates employment for many producer families and its entire value chain. However, cocoa exports to European markets are threatened by indications of contamination with heavy metals in cocoa destined for export, due to 
higher levels found compared to the values established by the European community. Therefore, cadmium contamination in food has become a concern in many countries.

Cadmium is a trace metal without essential biological functions, on the contrary, it is a toxic metal for plants, animals and humans in low concentrations. Part of the Cadmium is naturally released into the soil through the weathering of the rocks, which usually contain concentrations of the high inputs from anthropogenic sources, such as: mining, smelting, microelectronics industry and rock fertilizers that have increased significantly the cadmium content in many soils worldwide [1].

According to McLaughlin and Singh [2], cadmium, compared to other metals such as lead, is quite mobile in soils and is easily absorbed by plants. The high concentrations of Cadmium in the soil occur naturally or through anthropogenic activities. Natural production comes from the earth's crust and ocean water and can originate from geochemical processes related to volcanic eruptions or from the weathering of bedrock.

In this work, considering that there is no information about heavy metals in the area located in the Campo Verde-Honoria-Tournavista corridor, which is located between the Ucayali and Huánuco regions, we need to carry out the soil analysis and the analysis of cocoa beans in this corridor, to determine Cadmium values. In order to carry out this analysis, we propose a respective methodology to obtain samples from the aforementioned area. After the samples have been obtained, they are sent to the laboratory of the Faculty of Geological Mining and Metallurgical located at the National University of Engineering (FIGMM-UNI) located in the city of Lima, for chemical analysis. An atomic absorption spectrometer will be used, by means of which the concentrations of this metal in soil and beans will be obtained, for the subsequent analysis and statistical interpretation of results. Finally, the geochemical map design will be performed, which will show the distribution of cadmium on a local scale, based on the analyzes carried out for cadmium in samples collected.

This work is distributed as follows: In section 2 we review works related to the state of the art on the subject, then in section 3 we mention the current existing problems, later in section 4 we mention materials and methods used in this work, and in section 5 we show the statistical analysis of the experimental data that has been obtained. Finally, in section 6 we indicate conclusions and future work to be carried out.

\section{Review of the literature related to the subject}

The research will be carried out based on articles related to heavy metals and their relationship with cocoa. The bibliographic search was performed on different electronic databases.

Geologists, agribusinesses, and environmental engineers who have to deal with contaminated soils and other environmental media consider the naming of heavy metals in this context to be a convenient construct to refer to the range of metals and metalloids that can cause problems of Toxicity in the agricultural sector, especially in exports to the United States of America and Europe. Possibly many of these people continue to use it, even if it is poorly defined.

It should be mentioned that, first of all, according to geochemical considerations, Cadmium is known to be a calcophilic element and is closely related to Zinc. The volume of Cadmium in nature is dispersed as isomorphic impurities in various other minerals, usually in sulphurous minerals. The main one is sphalerite but cadmium is also dispersed in lead ore. In oxide zones, cadmium is mainly found in esmitsonite, sauconite, hemimorphite, manganese oxides, and hydrated iron oxides. During weathering, there are complex forms of cadmium in sulfate and chloride solutions.

A consequence of this suggests that this construct, related to heavy metals, tends to be used mainly in a pejorative sense, which refers to those elements that cause contamination problems and, therefore, undermine the quality of the land. This appreciation is unfortunate because several of the heavy metals are also essential for plants and/or animals and must be present in appropriate quantities. Some nonmetals, such as $\mathrm{As}, \mathrm{Sb}$, and Se that have the appearance and/or some of the properties of metals, but behave chemically as nonmetals, have sometimes been included within the 
group called heavy metals, which, of course, is not adequate, because its correct classification would be of metalloids [3].

According to Alloway [4], if the concentrations of heavy metals are so high in the soils of many areas, it can poison the plant's growth system, degenerating the soil and reducing the quality of crop products. Later, in Mendez, Ramirez, Gutierrez and Garcia [5] when Cadmium and Lead are found naturally in earth's crust in form of minerals, they can be absorbed by plants and taken from them by humans, and there is a potential health risk. Aikpokpodion [6] conducts a study to assess the impacts of copper-based fungicides on plantations in Nigeria's Ondo State. Soil contamination was assessed based on geoaccumulation. The results obtained suggest that alternative means of crop protection using biodegradable fungicides should be identified.

Huamani et al. [7] it is mentioned that the presence of heavy metals in cocoa crop is a serious problem for farmers and cooperatives in the Huánuco and Ucayali regions in Peru. In this work, the contents of Cadmium and Lead in soils and cocoa leaves of these regions were evaluated, samples taken from 22 plots with organic crops of this species were collected and analyzed in laboratory. Research by Takrama et al. [8] mention that cadmium is a toxic environmental pollutant. Cadmium occurs naturally and can accumulate in agricultural crops, and therefore enters the human food chain. In this work they also mention that cadmium has been detected in chocolate and other cocoa derivatives. Likewise, Amankwaah, Nnuro, Awudza and Afful [9], conducted a study of six heavy metals from four of main cocoa-producing regions in Ghana. These results showed the quantities of Cadmium in cocoa bean, to then compare with permitted standards of maximum total permitted concentrations of metals in cocoa and to be able to obtain some conclusions. On the other hand, Chávez et al. [10], carried out a research in south of Ecuador on concentration of Cadmium in plants and soils, for this, soil samples were collected in different plantations at different depths, while the samples of the plants were taken from nearby trees. The Cadmium content in cocoa beans was found above the critical level, causing concern in the consumption of cocoa-based chocolate.

In the same way, Arévalo et al. [11], mentioned that cocoa had a significant growth in recent years in Peru and the presence of heavy metals in soils of these plantations is a potential problem for exports of this product. The objective of this work was to determine the total quantities of heavy metals (especially Cadmium) in soils of cocoa plantations in the main production areas of Peru. Then, in the work of Gramlich et al. [12], mentioned that absorption of Cadmium by cocoa, attracted attention, after the European Union decided to establish tolerable values for cocoa products. In their study they analyze Cadmium concentrations in cocoa leaves, husks and seeds in crops located in Bolivia. In addition, they evaluated other parameters to be able to identify what factors influence the absorption of cadmium by cocoa trees.

The investigations of Gramlich et al. [13] carried out a study to identify the sources of Cadmium in the soils of cocoa plantations in Honduras. In this way, the aim is to identify the factors that allow it to accumulate in cocoa. In their work, 55 cocoa farms in Honduras are analyzed, analyzing the concentrations of Cadmium in the leaves, husks, seeds and cocoa beans, in addition, they try to find relation between the type of soil and tree. Regardless, Abt, Fong, Gray, and Robin [14] analyzed cocoa powder, milk chocolate, and cocoa bean products that were purchased, retail, in U.S. retail stores. The objective was to determine the Cadmium and Lead concentrations in cocoa products using an inductively coupled mass spectrometer. According to Alves, Oliveira, and Cadore [15], Cadmium is considered a carcinogenic element for humans and exposure to this element can mainly damage the "kidney and bones and an increased risk of cancer was observed even at very low levels of exposition. Among the non-smoking population, foods of plant origin, such as cocoa, are recognized as the main contributors to the intake of Cadmium."

Cadmium is a heavy metal of proven toxicity and with many restrictions in relation to exports, especially cocoa. This metal is mainly associated with zinc mineral deposits and the toxicity it can display on different crops. Their bioavailability in the lithosphere, associated with the relative mobility of these elements, which are already toxic in traces, is very important in terms of their potential to 
leach, and according to soil profiles, can make them concentrate and displace along the food chain until reaching human beings. This fact of bioaccumulation was mainly attributed to the ability of the plant, Theobroma cacao, to metabolize potentially toxic metallic elements such as Cadmium and Lead [15], which accumulate in roots, stems, leaves, fruits and seeds [16]. Different levels of concentration are evidenced depending on their taxonomic classification and the age of plantations [5].

Then in Arguello et al. [17], mention that recent regulation of Cadmium in chocolate, threatens the sustainability of cocoa production in Southwest America. As a result, in Ecuador, a national survey was carried out to identify the spatial distribution of $\mathrm{Cd}$ in cocoa beans, as well as the soil and agronomic factors involved. Regardless of the work by Anyimah-Ackah, Ofosu, Lutterodt, and Darko [18], the latest relevant available publications on Arsenic, Cadmium, Lead, and Mercury in cocoa beans and cocoa-based foods were synthesized, with the purpose of highlighting gaps to encourage research on these issues. The authors conclude that more research is required to clarify the effect of these contaminants in cocoa-based foods. Finally, in Zug et al. [19], carried out a study in Huanuco, a region of Peru, measuring Cadmium concentrations in defatted cocoa powder from unfermented seeds of 40 trees different belonging to 20 farms in that Region, and associated Cadmium levels with the soil, field management and nearby vegetation diversity in that area.

\section{Current Problems}

In this work, we have fundamentally mentioned the cocoa problem in our country, due to the presence of heavy metals. Cadmium is a heavy metal that has a varied toxicity to various human organs, and is classified as a human carcinogen by the International Agency for Research on Cancer of the World Health Organization [20].

Cadmium can be easily absorbed by plants, although it is not essential for production of crops, on the contrary, it can generate toxic effects in plants, animals and within the production chain of man, as it is a toxic heavy metal, not biodegradable and bio accumulable. In the specific case of cocoa, this peruvian agro-export product has high consumption worldwide in all social strata. Chocolate is produced from the cocoa tree; whose taxonomic name is Theobroma cacao. The presence of cocoa, milk and sugar in the composition of chocolates can help increase the intake of protein, carbohydrates, fats, minerals and vitamins.

On the other hand, various studies have confirmed the presence of traces of cadmium, potentially toxic, which has forced the Peruvian State to enact Ministerial Resolution, No. 0449-2018-MINAGRI [21]: Rapid impact agenda linked to maximum levels of cadmium in specific products such as cocoa and chocolate. This document claims that cocoa is a crop that is characterized by defending the ecology of the area, not only because it is a perennial crop, but is also grown in association with providing shade (as an agroforestry system constituting a measure of adaptation and mitigation to climate change); It is also an important source of employment generation that demands inputs, goods and services. The cocoa bean is a product of great commercial relevance for Peru, it is the fifth most important product at the national level, both by area and by number of producers.

In 2017, cocoa exports and its preparations exceeded 235 million dollars, which represent around $4 \%$ of total agricultural exports [21]. Cadmium is also known to be a heavy metal that is applied in different industrial processes; therefore, it is released into the environment; accumulating, in the water, soil, plants, among others. Therefore, food contaminated with cadmium is one of the main risk factors for human exposure, among them is cocoa [21].

In [22], they proposed a list of factors that regulate the processes of bioaccumulation of Cadmium by plants, adapted to our country. This is shown in Table 1 
Table 1. Factors related to absorption processes of heavy metals

\begin{tabular}{ll}
\hline \multicolumn{1}{c}{ Factors } & Effect of absorption of cadmium by plants \\
\hline $\mathrm{pH}$ & Edaphic factors \\
Soil Salinity & $\begin{array}{l}\text { The absorption process increases at a lower pH, that is, it is greater in } \\
\text { acidic soils. }\end{array}$ \\
$\begin{array}{l}\text { Cadmium concentration } \\
\text { Micronutrients }\end{array}$ & $\begin{array}{l}\text { Absorption increases with increasing cadmium concentration. } \\
\text { The absorption process is variable according to the nature and quantity } \\
\text { of micronutrients. }\end{array}$ \\
Macronutrients & $\begin{array}{l}\text { The absorption process is variable according to the nature and quantity } \\
\text { of macronutrients. } \\
\text { The absorption increases with increasing temperature. }\end{array}$ \\
\hline Temperature & Crop Factors \\
\hline Arable species & $\begin{array}{l}\text { The absorption process of heavy metals decreases according to the } \\
\text { following trend: }\end{array}$ \\
Vlant tissue & Legetables $>$ beans $>$ cereals $>$ fruits. \\
Sheet age & Old leaves $>$ young leaves.
\end{tabular}

According to Mendez, Ramirez, Gutierrez and Garcia [5], they mentioned that, since cadmium and lead are found naturally in the earth's crust in the form of minerals, it can be absorbed by plants and taken through them by humans, there being a potential risk to health. In the work of Huamani et al.[7], they mention that the presence of heavy metals in cocoa crop is a serious problem for farmers and cooperatives in Huánuco and Ucayali regions (located in Peru). In their work, the contents of Cadmium and Lead in soils and cocoa leaves of these regions were evaluated.

In studies by Zug et al. [19], they mentioned that cocoa accumulates Cadmium and can be potentially harmful to human health. Consequently, cocoa production in heavily contaminated soils should be avoided. Furthermore, the authors mention that cocoa products from South America, in particular, often exceed cadmium limits, but the factors influencing the absorption of Cadmium are not yet well studied. Finally, in the studies by Anyimah-Ackah, Ofosu, Lutterodt, and Darko [18], they indicated that more research is required to clarify the levels of contamination due to the $\mathrm{As}, \mathrm{Pb}$ and $\mathrm{Hg}$ metals, in specific foods based on cocoa.

\section{Materials and Method used}

We can deduce, from the identified problems, that currently the producers in the study area do not know the true dimension of the cocoa problem and do not have the capacity to face the problem of said contamination. For this reason, the main contribution of our work will be to generate a geochemical map of the cadmium in the study area, to later mitigate the heavy metals, in the areas where the greatest contamination by these metals is found.

The methodology to achieve the contribution of our work is shown in Figure 1. 


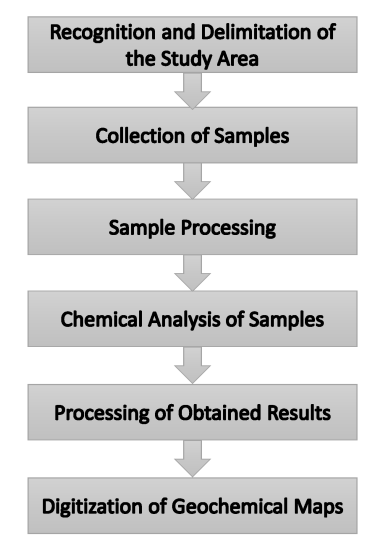

Figure 1. Methodology to achieve the contribution

- Recognition and delimitation of the study area This activity is carried out in the study area with the monitoring of a drone, obtaining images of the study area. This mapping activity was carried due to several flights.

- Collection of representative samples The regular grid method was used for sampling. According to selected area, the sampling will be carried out on a grid and with a certain spacing. Sampling was carried out inside a pit (making a V-shaped hole) between 30 to $50 \mathrm{~cm}$ deep in the ground [23], the fruit is collected from chosen trees within selected area. The extracted samples were: soil, grain and leaves that were stored in Ziploc bags, identifying them with a unique code and GPS positioning to obtain the exact location of the extracted samples. These samples are then delivery to FIGMM-UNI analysis laboratory, located in Lima-Peru.

- Sample processing The collected samples are pre-processed before the chemical analysis. If the samples are humid, the samples will be dried in stoves at a suitable temperature and without drafts that could contaminate the samples. Then, when the samples are dry, the grinding, quartering and sieving processes are carried out to obtain more homogeneous samples. These processes are carried out with soil, fruit and leaf samples. Subsequently, 1 gram of each sample is weighed for subsequent analysis.

- Chemical analysis of samples To determine the concentration of heavy metals in ppm, the samples are digested. In the case of soils, the heavy metal content was determined using the Environmental Protection Agency (EPA) method [24]. In the case of beans and seeds, the treatment used was [25]. In both cases solutions are obtained that will be analyzed with the help of an atomic absorption photometer spectrum, to obtain concentrations of heavy metals in soils, beans and leaves.

- Processing of obtained results Statistical processing of results obtained from heavy metals in soil, grain and leaf samples is performed. To do this, the R software [26] is used.

- Digitization of geochemical maps With all the information obtained, digital maps of each heavy metal in the area are made, for this, the ArcGIS software [27] is used.

The location of the study area, the method used, the preparation, digestion and chemical analysis of the samples collected in this study are detailed below. In many of the operations carried out, we have used various electronic equipment on the market that minimize contamination of cocoa with other components.

\subsection{Study area Location}

The work area is located in Honoria district, approximately $63.3 \mathrm{~km}$ away from Pucallpa district, leaving the city on a paved road that connects to the Central Highway for 45 minutes, you reach the district of Campoverde along the track $27 \mathrm{~km}$. from Pucallpa, in which there is a detour of the trail to 
Honoria district. The tour of the trail takes approximately 1 hour and 45 minutes, reaching the Fundo Cristina.

\subsection{Study area}

The study was carried out in cocoa plantations located in The Honoria Corridor of 12 hectares installed, but currently, 8 are in production. This delimitation was made with the aid of the PHANTOM 4 PRO drone. Figure 2 shows the limits of the area where all our work will be carried out.

The work zone is made up of 6 zones, divided according to the age of the cocoa plant, in that zone there are two varieties of cocoa: CCN51 and Creole-aromatic. In addition, maize exploitation areas were identified, prior to the cocoa plantations.

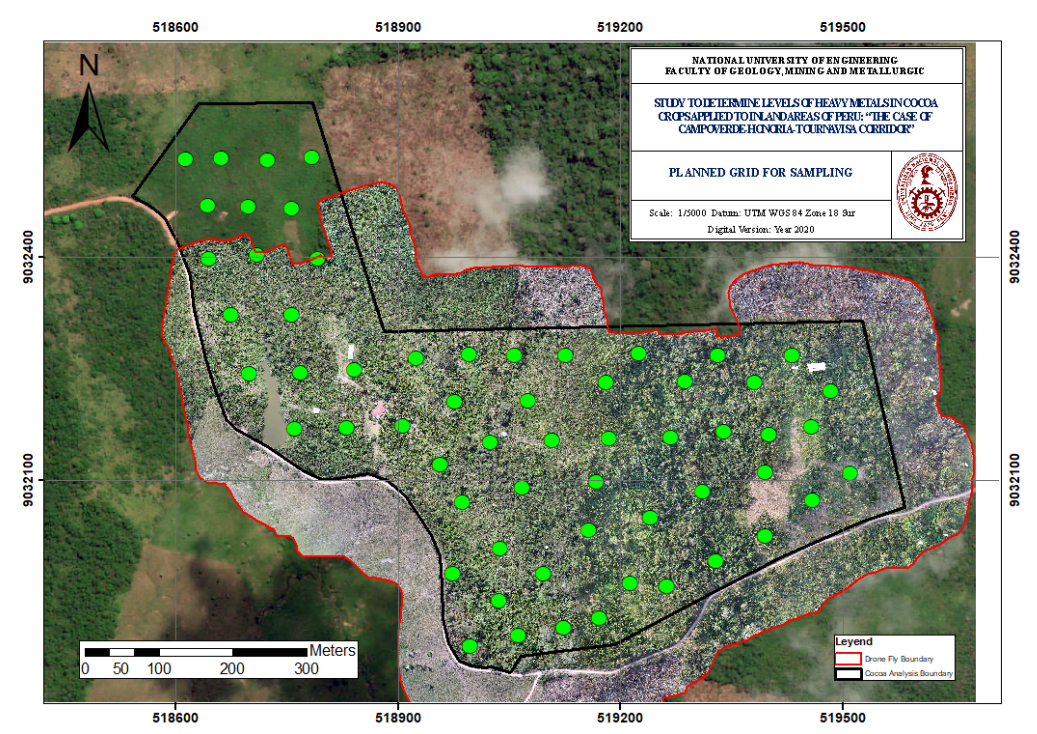

Figure 2. Delimitation of work area

\subsubsection{Geology of study area}

The Geological considerations at the local level mark the boundary within the Chambira formation, although this geology is general, the lithological description of this formation indicates that it has some dark gray sandstones, and is predominantly made up of red slates. Red slates contain several thin horizons of limestone and calcareous concretions. In Contamana region, red slates were found, with brown sandstones and marl beds, a one meter layer of volcanic scent at the bottom, and also fossiliferous; These considerations may be taken, but mainly we must consider that most of them are (recent) quaternary deposits which have as their main component the formation of soils due to their physical and chemical weathering. Figure 3 shows general geology of study area. 


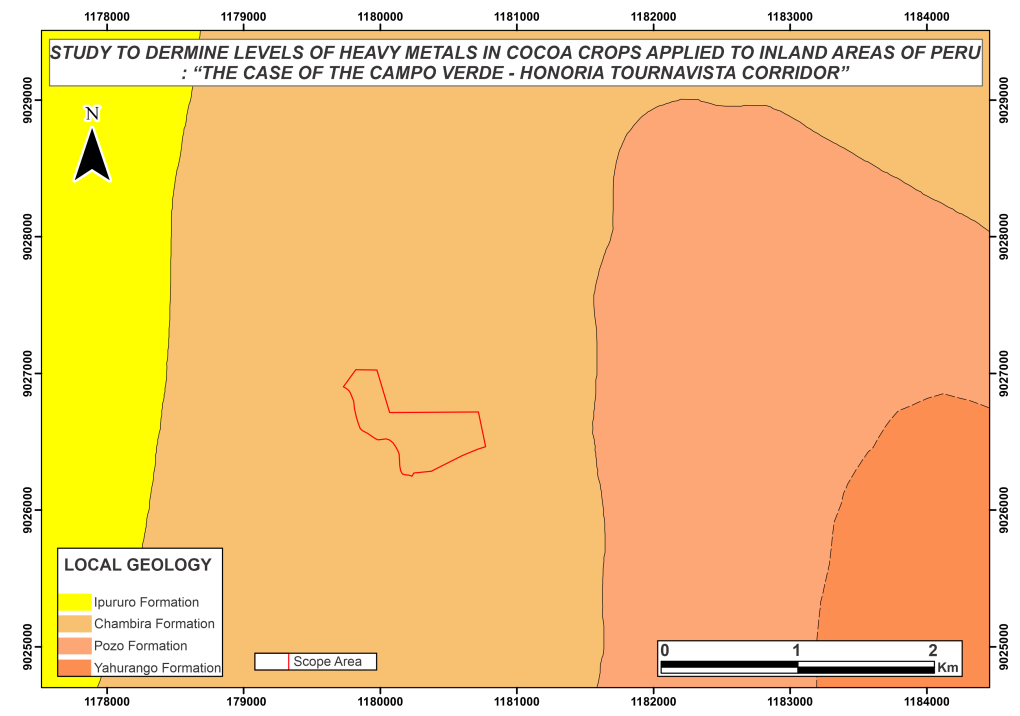

Figure 3. General geology of study area

4.3. Collection and processing of soils and cocoa fruits

\subsubsection{Soil and cocoa fruit sampling}

For soil sampling, a grid was made with a separation of $50 \mathrm{~m}$ east and $50 \mathrm{~m}$ north, the grid plane is shown in Figure 2, where a sample for analysis is collected for each point generated. The soil samples used for our study were collected at depths of $30 \mathrm{~cm}$, as indicated in the soil sampling guide, for agricultural soil [23]. More than 60 samples of approximately $01 \mathrm{~kg}$ each were programmed. The samples were conditioned in Ziploc bags and sent to FIGMM-UNI analysis laboratory and were: air-dried, ground, sieved and stored at room temperature. To achieve this, approximately $50 \mathrm{~cm}$ deep test pits were made on average for each point of the mesh that has been designed for the work area. See Figure 4.

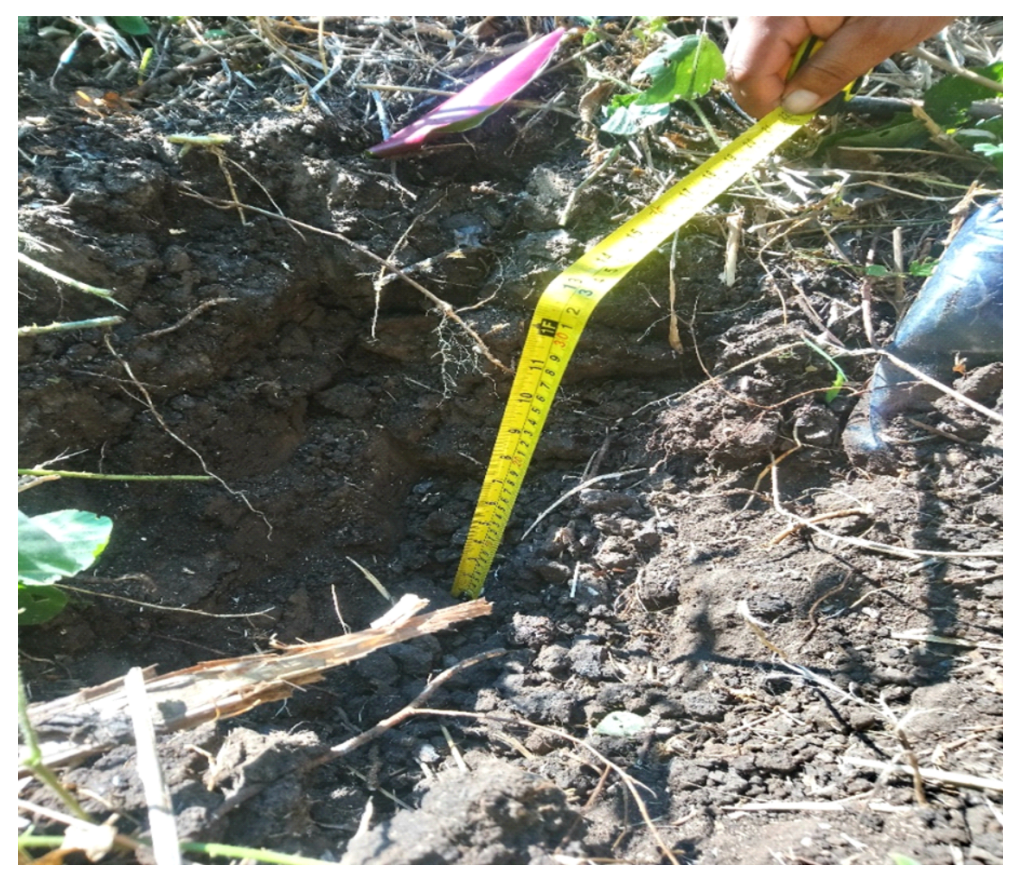

Figure 4. Test Pit 
From the test pit, a portion of soil is separated from a wall of the same test pit, considering that the sample should be a portion of soil that has not been in contact with the tool that was used to extract this sample. To collect the fruit, a machete was used to cut the union of this with plant with great care, in order not to contaminate the sample. Then, the fruit was taken with sterile polyethylene gloves to store it in Ziploc bags, assign its respective coding and finally, be sent to the FIGMM analysis laboratory at UNI located in Lima-Peru.

\subsubsection{Sample Processing}

The main operations to be carried out with the soil and cocoa fruit samples were: milling, quartering and sieving. With the soil samples arrived at the laboratory, the samples were first dried, which was carried out in a drying oven at a temperature of $105^{\circ} \mathrm{C}$. After the sample is dried, the grinding operation was carried out, and a Cole-Parmer brand jar mill was used, which contains burundum material as the grinding medium, ideal for wet or dry grinding. This equipment provided us with a homogeneous grinding, which allowed us to bring the sample to a desired grain size of 75 microns. In the case of cocoa fruits, the operations are quite similar, first the bean was separated manually and to reduce the size for chemical treatment, a grinding was used similar to the soils, using a mill small IKA brand, model A11 b. Then, sieving and quartering were carried out with the portable 1-column electric sieve. This equipment allowed us to bring the fruits up to a desired granulometry of 212 microns.

\subsubsection{Chemical analysis of samples}

Prior to the chemical analysis of the samples obtained, the samples were digested with acids and then solutions were prepared from the soil, grain and cocoa leaves samples, to achieve this, independently, the following was carried out:

\subsubsection{Digestion of soil samples}

Heavy metal content was determined by the Environmental Protection Agency [24]. Digestion was performed in a Thermo Scientific brand heater and in $100 \mathrm{ml}$ Kjeldahl flasks. To the $0.5 \mathrm{~g}$ of the dry and ground soil sample, $0.5 \mathrm{ml}$ of distilled water and $10 \mathrm{ml}$ of $70 \%$ nitric acid $\left(\mathrm{HNO}_{3}\right)$ were added. It was left to react at $100{ }^{\circ} \mathrm{C}$ for 2 hours in a bain-marie. Then, the sample contained in the flask is removed and allowed to cool for 15 minutes. Finally, $3 \mathrm{ml}$ of $30 \%$ hydrogen peroxide $\left(\mathrm{H}_{2} \mathrm{O}_{2}\right)$ is added, and it is heated at $100{ }^{\circ} \mathrm{C}$ for an additional 1 hour in a bain-marie.

\subsubsection{Digestion of samples of cocoa beans and leaves}

To 1 gram of the sample (bean or shell), $10 \mathrm{ml}$ of $70 \%$ nitric acid $\left(\mathrm{HNO}_{3}\right)$ was added, and the sample was allowed to react in cold for 20 minutes. Then, $3 \mathrm{ml}$ of $70 \%$ perchloric acid $\left(\mathrm{HClO}_{4}\right)$ was added, and heated to temperature of $200{ }^{\circ} \mathrm{C}$, up to volume of solution decreased to $5 \mathrm{ml}$. After digestion is complete, it is removed from the tray, allowed to cool and filtered with Whatman filter paper No. 42, in $25 \mathrm{ml}$ fiolas (small flasks), washed with distilled water up to $25 \mathrm{ml}$ volume, then it is covered and stirred [25].

\subsubsection{Atomic Absorption Analysis}

The samples in solution obtained from the digestion process were analyzed with an Atomic Absorption Spectrophotometer (AAS), brand GBC Scientific Equipment, model XplorAA. The element Cadmium under the wavelength of $228.8 \mathrm{~nm}$, the Lead under the wavelength of $217 \mathrm{~nm}$ and finally the Zinc under the wavelength of $213.9 \mathrm{~nm}$ were analyzed. With these obtained data, the statistical treatment of the data is carried out. Some partial data of these measurements are shown in Table 2 . These data were complemented with the $\mathrm{pH}$ and conductivity measurement. 
Table 2. Average concentration in soils of: $\mathrm{Cd}, \mathrm{Pb}, \mathrm{Zn}, \mathrm{pH}$ and conductivity.

\begin{tabular}{ccccccc}
\hline $\mathbf{X}_{\text {east }}$ & $\mathrm{Y}_{\text {north }}$ & $\mathrm{Cd}_{\text {soil }}$ & $\mathrm{Pb}_{\text {soil }}$ & $\mathrm{Zn}_{\text {soil }}$ & $\mathrm{pH}_{\text {approx }}$ & $\mathrm{C}_{\text {aprox }}(\mathrm{us} / \mathrm{cm})$ \\
\hline 518642,00 & 9032291,00 & 1,75 & 54,12 & 70,55 & 7,06 & 39,94 \\
518644,00 & 9032343,00 & 1,60 & 50,30 & 99,40 & 6,55 & 10,30 \\
518690,00 & 9032334,00 & 1,90 & 72,35 & 77,12 & 6,28 & 5,00 \\
518701,00 & 9032232,00 & 1,70 & 58,13 & 97,10 & 8,00 & 126,69 \\
518706,00 & 9032284,00 & 1,25 & 59,12 & 74,70 & 6,70 & 8,00 \\
518986,00 & 9032159,00 & 1,75 & 56,15 & 58,15 & 6,40 & 8,70 \\
519048,00 & 9031924,00 & 1,50 & 65,70 & 82,95 & 6,53 & 15,00 \\
519059,00 & 9031914,00 & 1,40 & 52,56 & 68,30 & 5,79 & 5,00 \\
519080,00 & 9031887,00 & 1,40 & 50,12 & 70,95 & 5,41 & 4,50 \\
519082,00 & 9031958,00 & 1,35 & 70,15 & 58,70 & 6,39 & 18,01 \\
519170,00 & 9031951,00 & 2,05 & 63,70 & 30,15 & 6,46 & 9,00 \\
519178,00 & 9032126,00 & 1,50 & 71,78 & 38,90 & 7,92 & 52,25 \\
519188,00 & 9032064,00 & 1,10 & 48,12 & 11,80 & 6,95 & 30,00 \\
519188,00 & 9032092,00 & 1,85 & 63,70 & 30,05 & 7,50 & 40,28 \\
519199,00 & 9031868,00 & 1,35 & 50,89 & 46,75 & 6,13 & 9,00 \\
519208,00 & 9031894,00 & 1,90 & 54,12 & 48,40 & 6,20 & 10,40 \\
519213,00 & 9031961,00 & 1,55 & 47,35 & 91,15 & 6,26 & 14,00 \\
519221,00 & 9031902,00 & 1,10 & 52,13 & 58,70 & 6,17 & 12,00 \\
519222,00 & 9031911,00 & 1,35 & 58,98 & 61,70 & 6,18 & 13,00 \\
519242,00 & 9031886,00 & 1,25 & 56,38 & 54,23 & 6,07 & 11,50 \\
519395,00 & 9032025,00 & 2,25 & 59,35 & 27,80 & 6,06 & 26,90 \\
519469,00 & 9032091,00 & 1,70 & 72,29 & 38,60 & 6,51 & 43,14 \\
519511,00 & 9032048,00 & 2,55 & 65,12 & 64,35 & 6,36 & 47,00 \\
519556,00 & 9032093,00 & 2,11 & 70,18 & 47,35 & 5,98 & 66,94 \\
\hline
\end{tabular}

\section{Statistical Data Analysis}

To carry out the statistical analysis, the work zone was divided into five sectors (zone 6 does not contain crops) based on an administrative criteria of field management that includes homogeneous geographical characteristics, accessibility and type of crops. Maize exploitation zones were identified prior to cocoa plantations, sandy or clayey zones, as well as CCN51 and Creole-aromatic cultivation zones as observed in Figure 5. These factors will be incorporated in statistical analysis in order to relate them to the contents of heavy metals in soil, stems and beans.

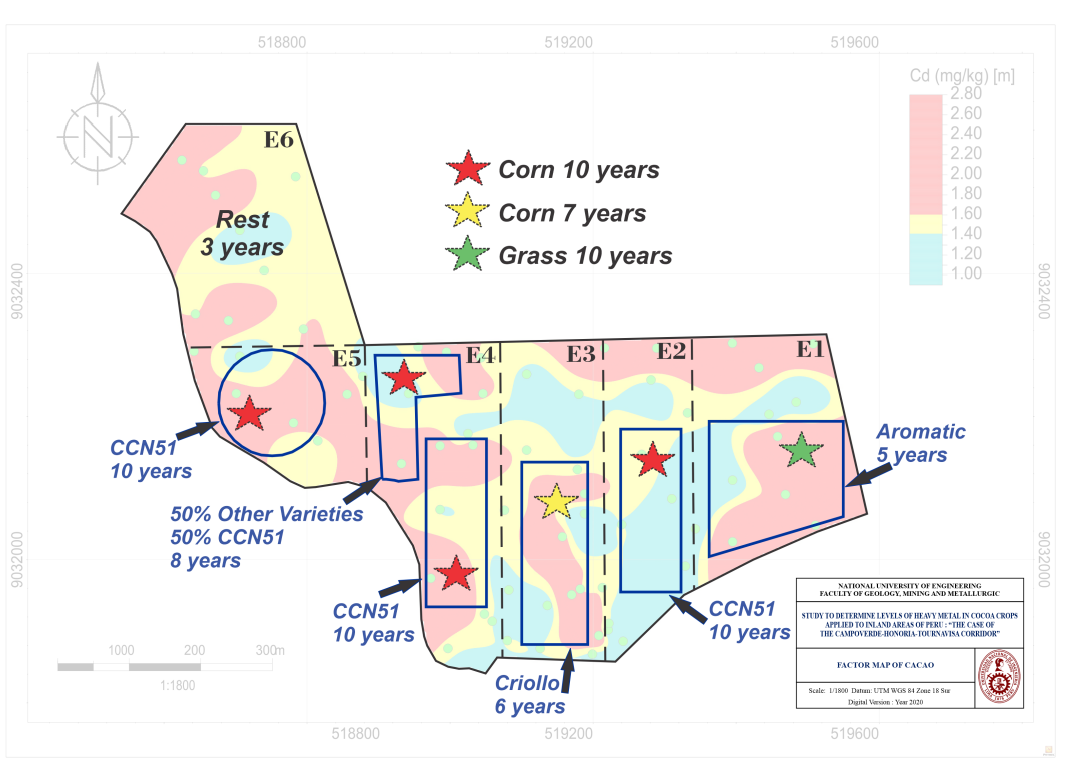

Figure 5. Age of plants and Intensity of land use 
Table 3 shows the statistical summary on content of heavy metals $(\mathrm{Cd}, \mathrm{Pb}$ and $\mathrm{Zn}$ ) according to the variety of cocoa in areas with cocoa crops. The acidity $(\mathrm{pH})$ and conductivity (EC) levels of these same soils are also included.

The data confirm that distribution of Cadmium in plant tissues and in plantation soils shows the following trend, both at the level of the entire productive unit and at the level of variety:

$$
C_{\text {beans }} \sim C_{\text {shells }}<C_{\text {soils }}<C_{\text {leaves }}
$$

These results confirm the findings of [28], [22], they conclude that average Cadmium concentration varies in different parts of the plant, showing the following general trend: roots $>$ stems $>$ leaves $>$ fruits $>$ seeds. According to the authors, between 70 and $80 \%$ of the Cadmium absorbed by the cocoa plantations is retained by roots and the rest moves to other parts of plant tissues, being bioaccumulated, depending on the location, on stems, leaves and lower proportion in shell and beans of cocoa. Research by [29], [30], confirms this hypothesis that plant tissues bioaccumulate higher concentrations than storage tissues, such as cocoa hulls and cocoa beans, which It allows to infer that presence of physiological barriers prevents the Cadmium bioaccumulation process in cocoa hulls and in cocoa beans.

It is observed that highest levels are registered in grains of Creole-aromatic varieties, which is directly related to highest levels of Cadmium concentration in soil. On the contrary, although Cadmium levels are lower in CCN51, the variability with respect to the average is higher in it. Therefore, these results will be complemented with an analysis of distribution of data.

Table 3. Summary statistics on heavy metal content in beans, soils and leaves according to cocoa variety $(\mathrm{mg} / \mathrm{kg})$

\begin{tabular}{|c|c|c|c|c|c|c|c|c|c|c|c|}
\hline Total & $\mathrm{Cd}_{\text {beans }}$ & $\mathrm{Pb}_{\text {beans }}$ & $\mathrm{Zn}_{\text {beans }}$ & $\mathrm{Cd}_{\text {soils }}$ & $\mathrm{Pb}_{\text {soils }}$ & $\mathrm{Zn}_{\text {soils }}$ & $\mathrm{Cd}_{\text {leaves }}$ & $P b_{\text {leaves }}$ & $\mathrm{Zn}_{\text {leaves }}$ & $\mathrm{pH}_{\text {approx }}$ & $\begin{array}{c}\mathrm{CE}_{\text {approx }} \\
\text { (us/cm) }\end{array}$ \\
\hline Media & 0.96 & 17.22 & 74.41 & 1.63 & 59.28 & 58.66 & 2.10 & 21.51 & 104.49 & 6.49 & 26.11 \\
\hline $\mathrm{DE}$ & 0.34 & 7.37 & 11.39 & 0.37 & 8.13 & 22.63 & 0.69 & 5.45 & 32.19 & 0.62 & 27.66 \\
\hline $\mathrm{CV}$ & $35 \%$ & $43 \%$ & $15 \%$ & $22 \%$ & $14 \%$ & $39 \%$ & $33 \%$ & $25 \%$ & $31 \%$ & $9 \%$ & $106 \%$ \\
\hline \multicolumn{12}{|l|}{ CCN51 } \\
\hline Media & 0.86 & 17.27 & 79.03 & 1.59 & 56.19 & 76.73 & 2.27 & 20.93 & 112.11 & 6.61 & 28.70 \\
\hline $\mathrm{DE}$ & 0.36 & 8.32 & 10.47 & 0.26 & 7.62 & 17.20 & 0.65 & 4.34 & 24.36 & 0.63 & 41.01 \\
\hline $\mathrm{CV}$ & $42 \%$ & $48 \%$ & $13 \%$ & $16 \%$ & $14 \%$ & $22 \%$ & $29 \%$ & $21 \%$ & $22 \%$ & $10 \%$ & $143 \%$ \\
\hline \multicolumn{12}{|c|}{ Creole-aromatic } \\
\hline Media & 1.07 & 20.97 & 69.72 & 1.83 & 64.93 & 38.63 & 2.08 & 24.49 & 102.25 & 6.68 & 37.06 \\
\hline $\mathrm{DE}$ & 0.33 & 6.48 & 12.28 & 0.46 & 7.69 & 16.29 & 0.82 & 5.58 & 40.10 & 0.65 & 17.93 \\
\hline $\mathrm{CV}$ & $31 \%$ & $31 \%$ & $18 \%$ & $25 \%$ & $12 \%$ & $42 \%$ & $39 \%$ & $23 \%$ & $39 \%$ & $10 \%$ & $48 \%$ \\
\hline
\end{tabular}

Figure 6 shows distribution of contents of Cadmium in soil, in areas with cocoa crops of productive unit a), according to sectors b) and previous exploitation of field in maize crops c). 


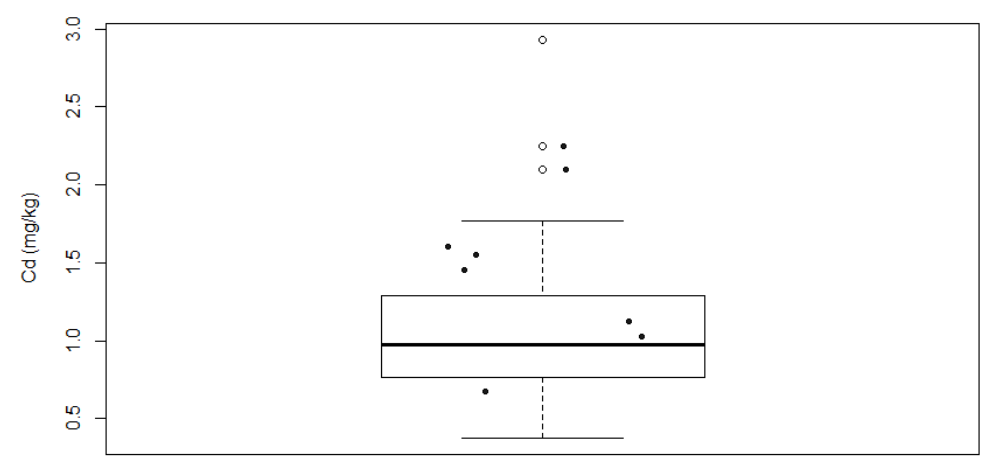

(a)

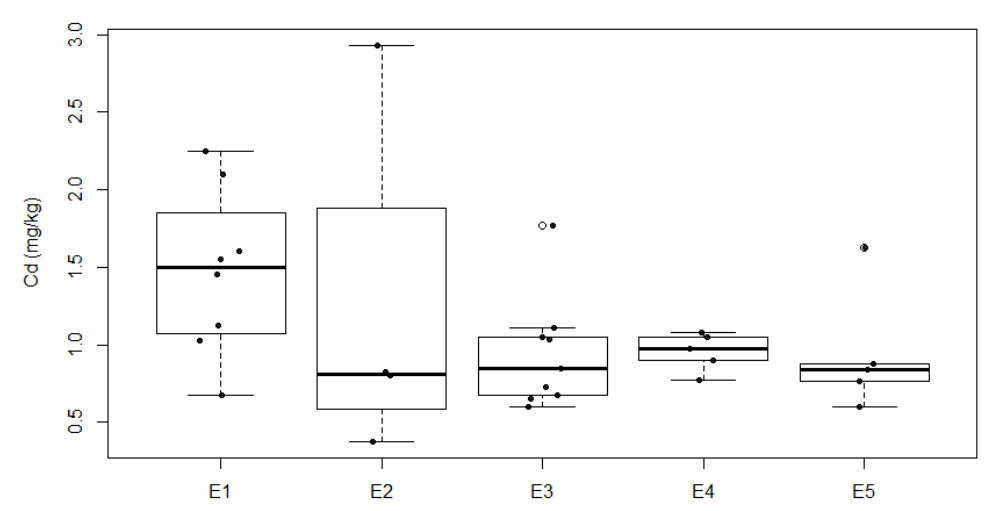

(b)

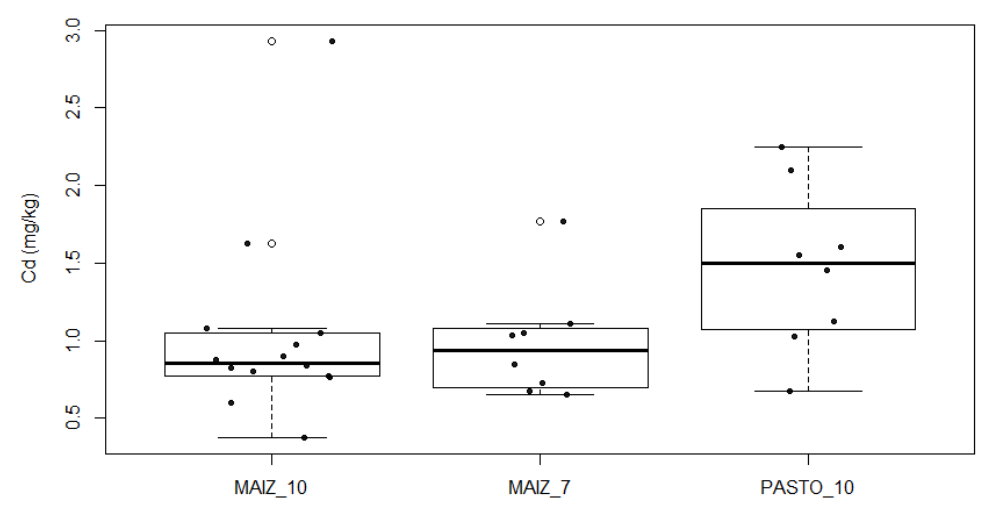

(c)

Figure 6. Cadmium content in soil: (a) cocoa crops; (b) sectors; (c) prior exploitation of field

The empirical distribution of measurements of Cadmium in soil in cocoa cultivated area, corresponding to Fundo Cristina (FC), shows a symmetric distribution but with extreme values, which can explain the increase in average content of Cadmium in varieties Creole-aromatic. It should be noted that more than $50 \%$ of values are below the maximum allowed of $1.4 \mathrm{mg} / \mathrm{kg}$ established in sampling guidelines for determination of Cadmium levels in soils, leaves, grains and products derived from cocoa [31]. As a result, it is observed that average value is less than median value 6(a).

By blocking the Cadmium measurements according to sectors 6(b), it is observed that the distribution of Cadmium in soil in these cocoa growing areas is different. The great difference between sectors E1 and E2 is notable. The first one shows a high average Cadmium content that exceeds the $1.4 \mathrm{mg} / \mathrm{Kg}$ allowable and a slightly asymmetric distribution that affects the average value, placing it above the median. On the contrary, in the second case, although the average content of Cadmium is 
very acceptable, the dispersion is high, observing an extreme value close to $3 \mathrm{mg} / \mathrm{kg}$. Sectors E3, E4 and E5 show very homogeneous data distributions and centered within permissible limits.

It is possible that the observed difference in distribution of Cadmium contents by sectors can be explained by previous land use and age of cocoa crop in the aforementioned sectors. To obtain evidence, we use graph 6(c) that shows the distribution of contents of Cadmium according to previous exploitation of the land. The graph presents three cases: first, land that has been planted with maize for 10 years since 1998 (MAIZ 10); second, land that since 2001 maize was sown for 7 years (MAIZ 7 ) and those that were pasture for 10 years (PASTO 10) before 2008. In this regard, it is observed that the content of Cadmium is higher in land than, since approximately 1998, they were pastures. Therefore, exploited lands where it cannot be cultivated because they are very poor in organic matter and scarce of shades. These lands correspond to sector E1. A similar result is observed in lands that had maize planting since 1998 and 2001 that correspond to sector E3, E4 and E5. Although the average is low, there are extreme values which correspond to the high values interpolated in geochemical map. It should be noted that these lands that were previously cultivated with maize, have already been recovered due to fertilizer (island guano) applied to cocoa crops that have existed for 8 years, which has not happened yet with the grass that is still in that process.

In Figure 7 , the hierarchical correlation matrix between the 11 variables analyzed is shown, considering data from the entire productive unit 7(a), blocking variety CCN51 7(b) and Creole-aromatic 7(c). A priori, it was determined that the correlation matrix should be constructed on the basis of three hierarchical groupings because three heavy metals were analyzed. When analyzing the data corresponding to the entire productive unit, figure $6 \mathrm{a}$, it is verified that the three measurements of Cadmium (soil, leaves, bean) are significantly correlated in the same group, although these contribute less to variability than Zinc and Lead respectively. Furthermore, of the three possible combinations (two to two) it is observed that the lowest is Cadmium soil with Cadmium grain. At the other extreme, we have Cadmium with Zinc, where in all cases, they are negatively correlated. Especially, Cadmium soil with Zinc grain where correlation is extreme negative. 


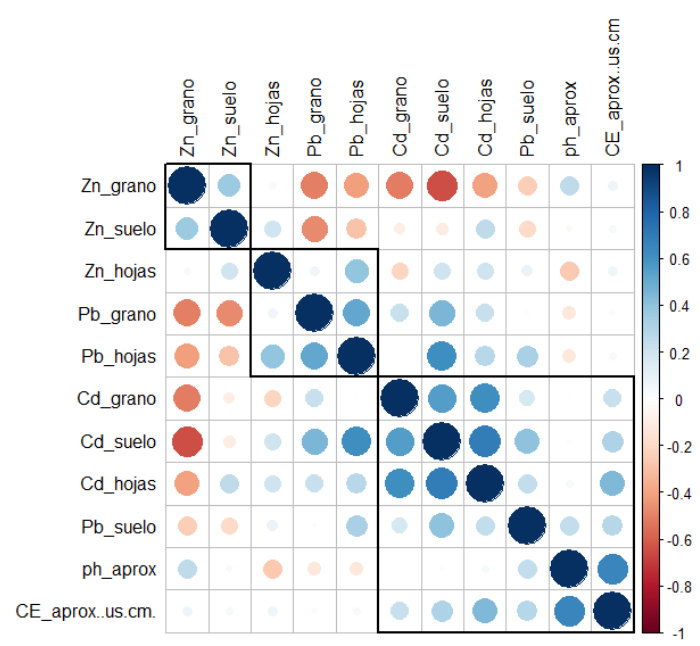

(a)

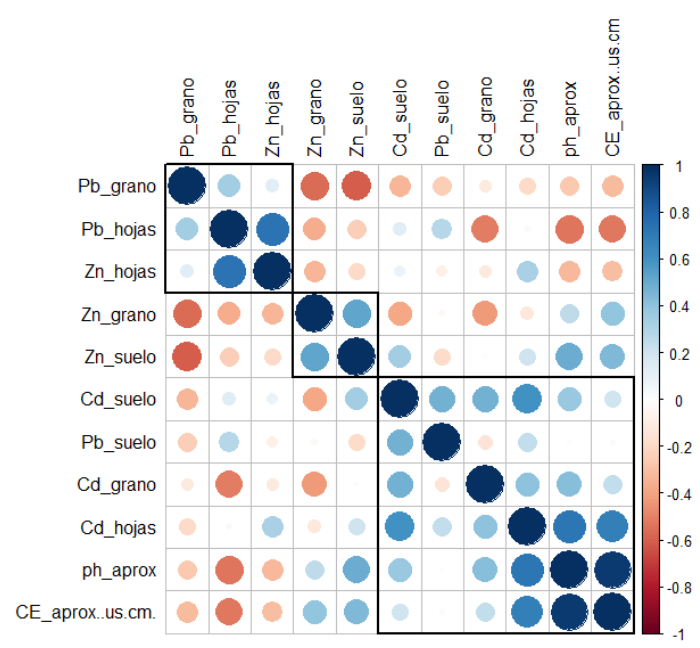

(b)

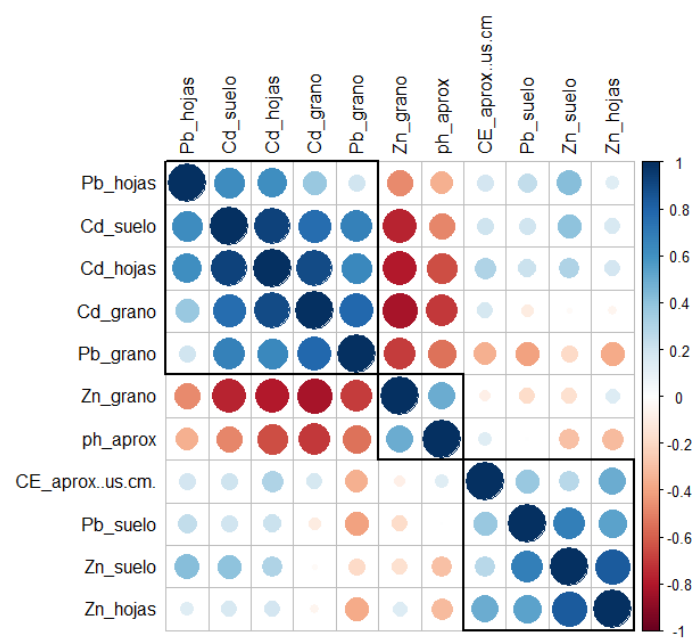

(c)

Figure 7. Correlation of heavy metals in soil, grain and leaves (a) The entire farm; (b) CCN51; (c) Creole-aromatic variety

Unlike what was observed in the correlation at the entire farm 7(a), the correlation structure in the variety CCN51 shows that the contribution of Lead in the total variation of the data is greater than 
Zinc. In both cases, the variability observed in the Cadmium contents is the one that least contributes to the total variability of the data. The correlations within groups are positive, which indicates the positive correlation in each one of the heavy metals analyzed in relation to the soil, grain and leaves.

However, the same does not happen in case of aromatic and creole varieties, as shown in 7(c). Unlike 7(a), Cadmium is added to the Lead contribution observed in 7(b). In this case, amounts of Cadmium are the ones that explain the highest proportion of total variability and maintain positive correlation within groups. Additionally, the negative correlation of grain Zinc with the content of Cadmium in soil, grain and leaves is highlighted in Creole and aromatic variety. Grain lead now correlates positively and significantly with Cadmium contents, which in the general case did not. It is important to mention that $\mathrm{CCN} 51$ variety is found in clay soils unlike the Creole and aromatic varieties where soils are not only clayey but also sandy. In the latter case, land has been pasture, which indicates extreme exploitation of land.

Figure 8 shows a representation of observations and variables analyzed by a Biplot, of main components, at $51.7 \%$ of total inertia [32]. Variable targeting and position of sample observations were validated by a SQ Biplot for diagnosis [33], [34]. Horizontal axis is mainly represented by Cadmium variables in soil, leaves and grain, therefore it will represent Cadmium dimension. Vertical axis that is represented by electrical conductivity ( $\mathrm{CE}$ aprox) and the $\mathrm{pH}(\mathrm{pH}$ aprox) will be the $\mathrm{CE} \mathrm{pH}$ axis. Regarding observations, it is verified that they are contained in a Gaussian interval of $90 \%$ with the exception of record 4 , which is completely defined by the $\mathrm{CE} \mathrm{pH}$ axis.

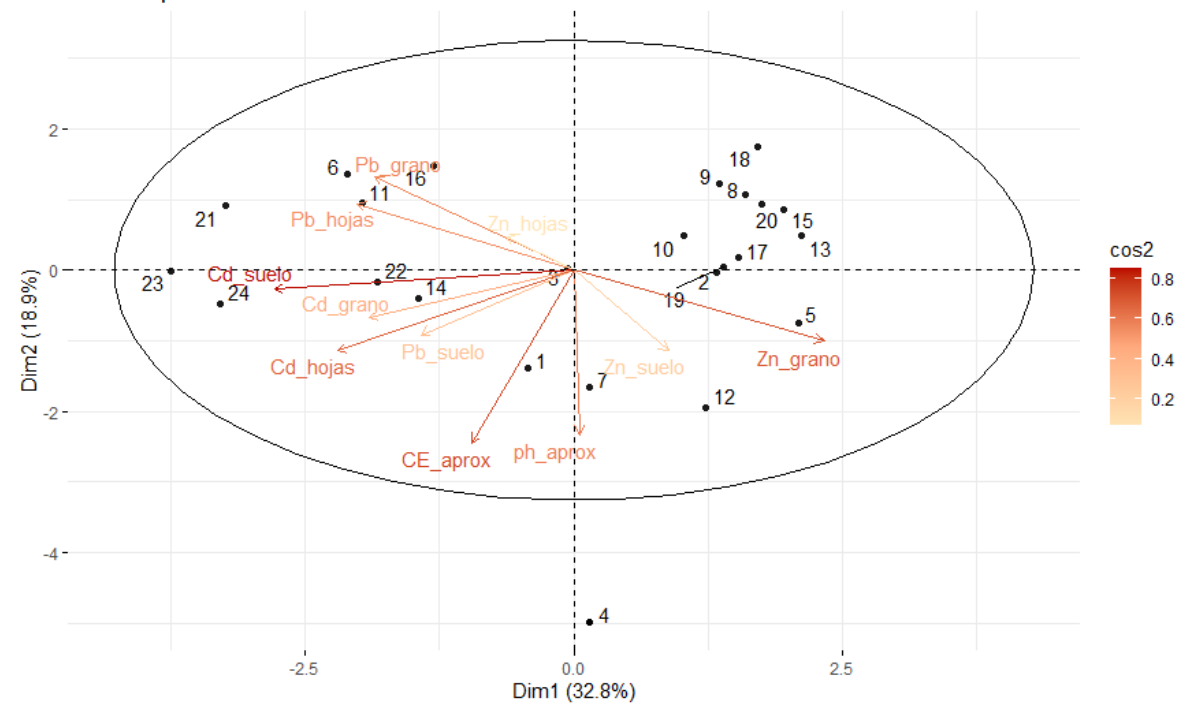

Figure 8. Biplot for Principal Component Analysis of sample and analyzed variables

In Figure 8, it is possible to distinguish definition of two extreme groupings along the horizontal axis, which would be indicating that the Cadmium dimension is an important discrimination factor. At the extreme left are observations collected in sector E1, which represents the highest values in soil Cadmium and were pasture areas, currently, with aromatic-Creole crops in the process of recovery. In the extreme right, formed by observations of sectors E2 and E3, with lower levels in Cd, formed by Creole-aromatic crops and CCN51 where corn was cultivated for more than 7 years, but currently they are recovered territories.

Regarding the $\mathrm{CE} \mathrm{pH}$ dimension, it can be seen that the observations corresponding to sector E5, whose trees are 10 years old, are well represented on this axis. The $\mathrm{pH}$ values are well above the average of 6.49 and $26.11 \mathrm{us} / \mathrm{cm}$ in electrical conductivity, see table 2. The observations of the other sectors are distributed in the vicinity of the mean value of the $\mathrm{CE} \mathrm{pH}$ axis with a slight bias towards values below the average. This bias is more evident in the observations taken in sectors E2 and E3 where there are Creole-aromatic varieties and CCN51. This dispersion of the data around the mean 
$\mathrm{pH}$ and EC values indicates a predisposition of the soil to respond positively in the medium term to any remediation measure aimed at reducing the absorption of Cadmium in cocoa crops.

\subsection{Cadmium Geochemical Map}

With the measurements taken at Fundo Cristina, the geochemical map of Cadmium soils for the study area was generated. The data obtained confirmed that in the case of soils, the average Cadmium concentration of $1.63 \mathrm{mg} / \mathrm{kg}$ is above the international standards of the European Union, the value of which is $1.4 \mathrm{mg} / \mathrm{kg}$. The map shows the distribution of the element Cadmium based on its concentration in the area, it should be noted that, due to the interpolation process, there are areas that may have low values, but due to some extreme values close to these, the map is affected to some extent because of it. This does not occur in sectors E1 and E2, in which it is evident that the differences in Cadmium content are less in sector E1 compared to sector E2, shown in Figure 9.

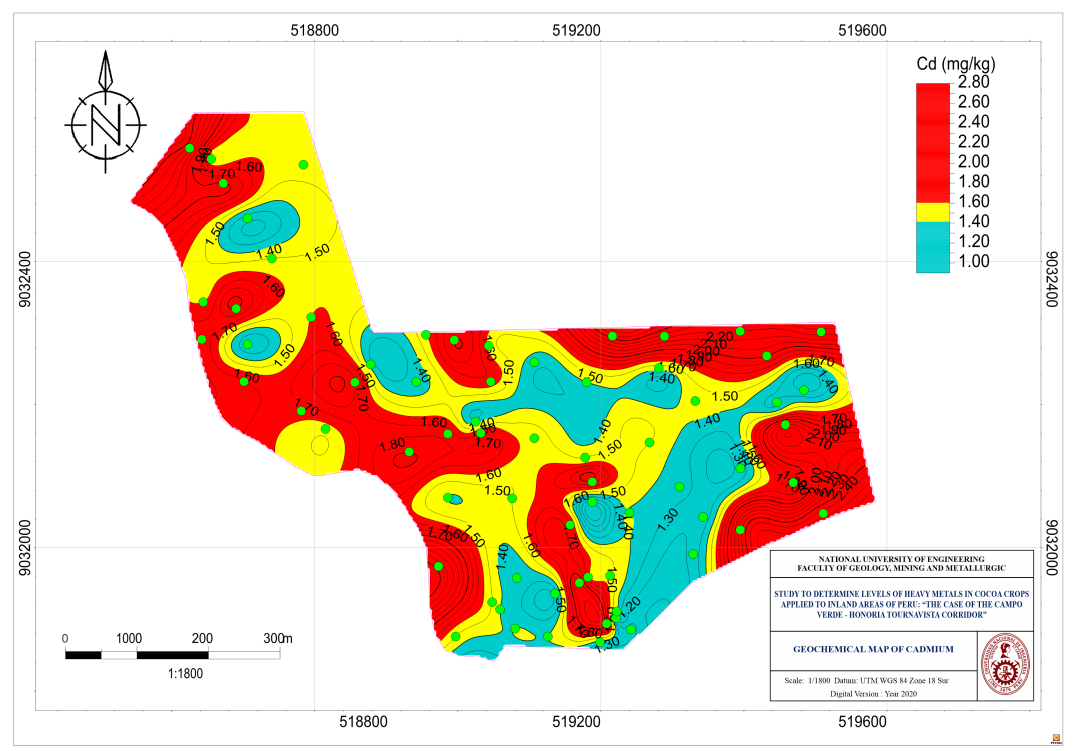

Figure 9. Cadmium Geochemical Map in soils

\section{Conclusions}

The data collected allowed obtaining statistical information on the contents of Cadmium, Lead and Zinc in soil, leaves and grain, in addition to $\mathrm{CE}$ and $\mathrm{pH}$ in the study area. Factors such as previous exploitation of soil [5], [7],[19], age and variety of cocoa trees have also been included [16], in order to complement research such as those carried out by [13],[15].

The experimental evidence related to levels of cadmium in plant tissues and, in soils of The Campo Verde-Honoria Tournavista plantations show the following trend, both at level of the entire productive unit and at level of variety:

$$
C_{\text {beans }} \sim C_{\text {shells }}<C_{\text {soils }}<C_{\text {leaves }}
$$

Although the research is descriptive, it was necessary to design data collection according to the updated progress of the research. The study has confirmed the relationship and correlation established between factors that regulate the processes of Cadmium bioaccumulation by plants [22],[28]. However, do not confirm that variety or age of tree clarify about cadmium absorption.

Although it is evident that over-exploited soils until their exhaustion tend to establish undesirable Cadmium absorption conditions, and, the fertilization of the soil with island guano for a period of not less than 5 years seems to reverse the phenomenon. Hence, statistical information confirms that the 
oldest sector is not defined in Cadmium dimension, on the contrary, it strengthens the conditions of $\mathrm{CE}$ and $\mathrm{pH}$ of soil for the balance of nutrients in the soil.

The data obtained in this study confirmed that in the case of soils, the average Cadmium concentration of $1.63 \mathrm{mg} / \mathrm{kg}$, is above the international standard of the European Union whose value is $1.4 \mathrm{mg} / \mathrm{kg}$, therefore, it is necessary to adopt measures to mitigate the aforementioned values, in order to comply with the requirements. In this work, the previous knowledge of the aspects of field management, as well as the current knowledge of the cocoa crops in the "Fundo Cristina", was essential to guide the research, and was useful to take actions that allow compliance with the requirements imposed. Therefore, we can conclude that it is essential to carry out future research aimed at proposing measures to solve current situation and avoid of Cadmium absorption in cocoa tree.

Author Contributions: For research articles with several authors, a short paragraph specifying their individual contributions must be provided. The following statements should be used "conceptualization, X.X. and Y.Y.; methodology, X.X.; software, X.X.; validation, X.X., Y.Y. and Z.Z.; formal analysis, X.X.; investigation, X.X.; resources, X.X.; data curation, X.X.; writing-original draft preparation, X.X.; writing-review and editing, X.X.; visualization, X.X.; supervision, X.X.; project administration, X.X.; funding acquisition, Y.Y.", please turn to the CRediT taxonomy for the term explanation. Authorship must be limited to those who have contributed substantially to the work reported.

Funding: The study was funded by the Vice-Rector for Research of the National University of Engineering.

Acknowledgments: In this section you can acknowledge any support given which is not covered by the author contribution or funding sections. This may include administrative and technical support, or donations in kind (e.g., materials used for experiments).

Conflicts of Interest: The authors declare no conflict of interest.

\section{Abbreviations}

The following abbreviations are used in this manuscript:

MDPI Multidisciplinary Digital Publishing Institute

DOAJ Directory of open access journals

TLA Three letter acronym

LD linear dichroism

\section{References}

1. ROSS, S.M. Sources and forms of potentially toxic metals in soil-plant systems. Toxic metals in soil-plant systems 1994, pp. 3-25.

2. McLaughlin, M.J.; Singh, B.R. Cadmium in soils and plants. In Cadmium in soils and plants; Springer, 1999; pp. 1-9.

3. Alloway, B.J. Heavy metals in soils: trace metals and metalloids in soils and their bioavailability; Vol. 22, Springer Science \& Business Media, 2012.

4. Alloway, B. Toxic metals in soil-plant systems. United Kingdom, $469 p 1994$.

5. Méndez, J.P.; Ramírez, C.A.G.; Gutiérrez, A.D.R.; García, F.P. Contaminación y fitotoxicidad en plantas por metales pesados provenientes de suelos y agua. Tropical and subtropical Agroecosystems 2009, 10, 29-44.

6. Aikpokpodion Paul, E. Assessment of heavy metals pollution in fungicide treated Cocoa plantations in Ondo state, Nigeria. Journal of Applied Biosciences 2010, 33, 2037-2046.

7. HuamanI-Yupanqui, H.A.; ángel Huauya-Rojas, M.; Mansilla-Minaya, L.G.; Florida-Rofner, N.; Neira-Trujillo, G.M. Presencia de metales pesados en cultivo de cacao (Theobroma cacao L.) orgánico. Acta agronómica 2012, 61, 339-344.

8. Takrama, J.; Afrifa, A.A.; Ofori-Frimpong, K.; Jonfia-Essien, W.A.; Agyemang, P.; Galyuon, I. Cadmium contamination of cocoa beans and cocoa growing agricultural soils of Ghana: There is no cause for public alarm. Peak Journal of Public Health and Management 2015, pp. 56-61.

9. Amankwaah, D.; Nnuro, W.; Awudza, J.; Afful, S. Determination of heavy metals in cocoa beans from some major cocoa growing regions in Ghana. Food Science and Technology 2015, 16, 225. 
10. Chavez, E.; He, Z.; Stoffella, P.; Mylavarapu, R.; Li, Y.; Moyano, B.; Baligar, V. Concentration of cadmium in cacao beans and its relationship with soil cadmium in southern Ecuador. Science of the Total Environment 2015, 533, 205-214.

11. Arévalo-Gardini, E.; Obando-Cerpa, M.E.; Zúñiga-Cernades, L.B.; Arévalo-Hernández, C.O.; Baligar, V.; He, Z. Metales pesados en suelos de plantaciones de cacao (Theobroma cacao L.) en tres regiones del Perú. Ecología aplicada 2016, 15, 81-89.

12. Gramlich, A.; Tandy, S.; Andres, C.; Paniagua, J.C.; Armengot, L.; Schneider, M.; Schulin, R. Cadmium uptake by cocoa trees in agroforestry and monoculture systems under conventional and organic management. Science of The Total Environment 2017, 580, 677-686.

13. Gramlich, A.; Tandy, S.; Gauggel, C.; López, M.; Perla, D.; Gonzalez, V.; Schulin, R. Soil cadmium uptake by cocoa in Honduras. Science of The Total Environment 2018, 612, 370-378.

14. Abt, E.; Fong Sam, J.; Gray, P.; Robin, L.P. Cadmium and lead in cocoa powder and chocolate products in the US Market. Food Additives \& Contaminants: Part B 2018, 11, 92-102.

15. Alves Peixoto, R.R.; Oliveira, A.; Cadore, S. Risk assessment of cadmium and chromium from chocolate powder. Food Additives \& Contaminants: Part B 2018, 11, 256-263.

16. Llatance, W.O.; Saavedra, C.J.G.; Castillo, W.G.; Mondragón, E.P. Bioacumulación de cadmio en el cacao (Theobroma cacao) en la Comunidad Nativa de Pakun, Perú. Revista Forestal Del Perú 2018, 33, 63-75.

17. Argüello, D.; Chavez, E.; Lauryssen, F.; Vanderschueren, R.; Smolders, E.; Montalvo, D. Soil properties and agronomic factors affecting cadmium concentrations in cacao beans: A nationwide survey in Ecuador. Science of the total Environment 2019, 649, 120-127.

18. Anyimah-Ackah, E.; Ofosu, I.W.; Lutterodt, H.E.; Darko, G. Exposures and risks of arsenic, cadmium, lead, and mercury in cocoa beans and cocoa-based foods: a systematic review. Food Quality and Safety 2019, 3, 1-8.

19. Zug, K.L.M.; Yupanqui, H.A.H.; Meyberg, F.; Cierjacks, J.S.; Cierjacks, A. Cadmium accumulation in Peruvian cacao (Theobroma cacao L.) and opportunities for mitigation. Water, Air, E Soil Pollution 2019, $230,72$.

20. Cadmium in the Human Environment: Toxicity and Carcinogenicity. https://publications.iarc.fr/BookAnd-Report-Series / Iarc-Scientific-Publications / Cadmium-In-The-Human-Environment-Toxicity-AndCarcinogenicity-1992, accessed Feb 3, 2020.

21. Resolucion Ministerial 449-2018. http://minagri.gob.pe/portal/download/pdf/normas-legales/ resolucionesministeriales/2018/noviembre/rm449-2018-minagri.pdf, accessed Feb 3, 2020.

22. Guia de manejo fitosanitario y la inocuidad en el Cacaotal 2017. http://repositorio.iica.int/bitstream/ handle/11324/6456/BVE18029639e.pdf;jsessionid=167C0B852C59B94ACBF924E1EB010489? sequence=1, accessed Feb 3, 2020.

23. Sabroso, M.; Pastor, A. Guía sobre suelos contaminados. Zaragoza 2004.

24. Epa, U. Method 3050B. Acid Digestion of Sediments, Sludges, and Soils. Revision 1996, 2, 12.

25. Rice, E.; Baird, R.; Eaton, A.; Clesceri, L. Standard Methods Fort he Examination of Water and Wastewater. Part 2012, 2540, 2-66.

26. R software. https://www.r-project.org/, accessed Feb 3, 2020.

27. ArcGIS Pro, software. https://www.esri.com/es-es/arcgis/products/arcgis-pro/overview, accessed Feb 3, 2020.

28. Nigam, R.; Srivastava, S.; Prakash, S.; Srivastava, M. Cadmium mobilisation and plant availability-the impact of organic acids commonly exuded from roots. Plant and Soil 2001, 230, 107-113.

29. Cieśliński, G.; Van Rees, K.; Huang, P.; Kozak, L.; Rostad, H.; Knott, D. Cadmium uptake and bioaccumulation in selected cultivars of durum wheat and flax as affected by soil type. Plant and soil 1996, 182, 115-124.

30. McGrath, S.; Zhao, F.; Dunham, S.; Crosland, A.; Coleman, K. Long-term changes in the extractability and bioavailability of zinc and cadmium after sludge application. Journal of Environmental Quality 2000, 29, 875-883.

31. Resolucion Ministerial 0451-2018. http://minagri.gob.pe/portal/resoluciones-ministeriales/rm-2018/ 22560-resolucion-ministerial-n-0451-2018-minagri-2, accessed Feb 3, 2020.

32. Lê, S.; Josse, J.; Husson, F.; others. FactoMineR: an R package for multivariate analysis. Journal of statistical software 2008, 25, 1-18. 
19 of 19

33. Gabriel, K.R.; Odoroff, C.L. Biplots in biomedical research. Statistics in medicine 1990, 9, 469-485.

34. Gower, J.C.; Lubbe, S.G.; Le Roux, N.J. Understanding biplots; John Wiley \& Sons, 2011. 